\title{
EVALUASI RADIOGRAFIK TERHADAP KETINGGIAN DAN DENSITAS TULANG ALVEOLAR MANDIBULA SETELAH PENGGUNAAN GIGI TIRUAN LENGKAP DENGAN TISSUE CONDITIONER PADA WANITA PASCA MENOPAUSE
}

\author{
Rahardyan Parnaadji, Zahreni Hamzah, Ady Soesetijo \\ Bagian Prostodonsia FKG Universitas Jember
}

Rahardyan Parnaadji, Zahreni Hamzah, FX Ady Soesetijo. Evaluasi radiografik terhadap ketinggian dan densitas tulang alveolar mandibula setelah penggunaan gigi tiruan lengkap dengan tissue conditioner pada wanita pasca menopause. Indonesian Journal of Dentistry 2005; 12 (2):80-84.

\begin{abstract}
The need for women to use a dental prosthesis increases with age. Low estrogen level is characteristic in post menopausal women. In this case, it often related with reduction of density and mandibular alveolar bone height. This study aimed to investigate the differences in density and mandibular alveolar bone height in post-menopausal women wearing complete dentures with tissue conditioner. The clinical observations were conducted on seven persons who had received a new set of complete denture in the Prosthodontic Department of the Dental Hospital of the Dental Faculty in Jember University. Balanced occlusion was used in all dentures, fabricated according to the principles used in the department. Panoramic radiographs had been made for all subjects as the baseline, and two, four, and six months later using dentures with tissue conditioner. The data was analyzed by using one-way analysis of variance at the 0.05 level. The conclusion was that there is no significant difference in density and mandibular alveolar bone height of complete denture wearers with tissue conditioner in post-menopausal women.
\end{abstract}

Key words: density, height, mandibular alveolar bone, tissue conditioner, post-menopausal women.

\section{Pendahuluan}

Dampak keberhasilan program kesehatan nasional adalah meningkatnya usia harapan hidup di Indonesia, sehingga populasi penduduk berusia lanjut (usila) juga meningkat. Pada keadaaan tersebut, usia lanjut yang berjenis kelamin wanita cenderung lebih banyak dibandingkan dengan lakilaki. ${ }^{1}$ Pada usia lanjut ini, terjadi perubahan- perubahan degeneratif, fisiologis dan biologis yang sangat kompleks pada jaringan tubuh. ${ }^{2}$ Masalah yang muncul pada kelompok usia lanjut antara lain, hygiene mulut yang buruk karena keengganan atau ketidakmampuan merawat gigi dan mulutnya, keengganan makan karena kerusakan serta kegoyangan gigi geligi, kehilangan gigi geligi, gigitiruan yang tidak dapat berfungsi berkurangnya 
aliran saliva, mukosa mulut lebih pucat dan kering dan lain-lain. ${ }^{3-4}$

Keadaan jaringan keras pendukung gigi tiruan pada kelompok wanita usia lanjut (45-90 tahun) dapat mengalami penurunan densitas tulang mandibula dari 1,9 menjadi 1,5. Penurunan densitas tulang ini menyebabkan tulang menjadi rapuh dan tidak mampu menyangga gigi tiruan, sehingga keberadaan gigitiruan dapat menyebabkan perubahan yang tidak menguntungkan pada jaringan pendukungannya.'

Hasil penelitian Kribs $(1990)^{5}$ menúnjukkan bahwa adanya hubungan antara densitas tulang mandibula dengan tulang skletal, serta adanya pengaruh langsung osteoporosis pada tulang mandibula. Hal ini dapat diasumsikan bahwa apabila densitas mandibula berkurang dapat dicurigai terjadi osteoporosis. Disamping itu beban yang besar pada tulang akan menghambat sirkulasi darah pada tulang dan menyebabkan terjadinya penurunan ketinggian tulang alveolar (resorbsi tulang).

Selain penyusutan densitas tulang, pada kelompok wanita usia lanjut juga mengalami penurunan ketinggian tulang alveolar. Keadaan ini juga dikenal sebagai proses resorbsi tulang alveolar dan sering dikeluhkan terjadinya pada bagian rahang bawah. Terjadinya resorbsi yang progresif pada rahang bawah seringkali dihubungkan dengan keluhan rasa sakit yang subyektif. Keluhan ini seringkali dihubungkan dengan keberadaan foramen mentale, sehingga tekanan gigi tiruan dapat menyebabkan parathesia di daerah nervus mentale. Disamping itu, resorbsi yang progresif dapat juga menyebabkan gigi tiruan menjadi mudah lepas, apabila dipergunakan untuk berfungsi. Keadaan ini dapat mengakibatkan rasa tidak nyaman pada pemakainya.'

Perubahan pada jaringan pendukung gigitiruan merupakan pertimbangan digunakannya tissue conditioner untuk melapisi tissue bearing surface gigitiruan. Pada beberapa keadaan tertentu, misalnya jaringan lunak yang mendukung gigi tiruan menunjukkan adanya gejala atropi, maka untuk mencegah rasa nyeri ataupun mengurangi tekanan pada jaringan keras rongga mulut, dilapisi tissue conditioner. $^{6}$

Oleh karena itu, diperlukan pengkajian yang lebih seksama dengan penelitian yang ditujukan untuk mendukung upaya peningkatan kualitas pelayanan prostodonsia di masa mendatang, terhadap kualitas tulang alveolar. Tujuan Penelitian ini adalah mengetahui densitas dan ketinggian tulang alveolar mandibula setelah penggunaan gigitiruan dengan tissue conditioner pada wanita usia lanjut pasca menopause.

\section{Bahan Dan Cara Kerja}

Jenis penelitian adalah observasional klinis dengan rancangan penelitian the pretest-posttest control group design. Subyek penelitian ini ditentukan dengan kriteria: (a) wanita dengan umur 50 - 65 tahun yang pasca menopause, (b) tidak mengidap penyakit diabetes mellitus, (c) edentulous ridge pada rahang atas dan bawah, (d) indikasi penggunaan tissue conditioner (mukosa atropi, resorbsi residual ridge dan lain-lain), dan (e) mengisi informed consent. Teknik pengambilan sampel adalah total sampling dengan jumlah sampel 7 orang.

\section{Persiapan penelitian}

Gigitiruan dibuat oleh kelompok peneliti sesuai standart klinis yang telah ditetapkan. ${ }^{7}$ Gigi tiruan resin akrilik yang telah selesai, pada bagian rahang bawah sedikit dibuat pengasaran, kemudian mengaduk bahan tissue conditioner dan diletakkan pada tissue bearing surface.

\section{Pengukuran densitas tulang alveolar mandi- dibula}

Sebelum dilakukan pemasangan gigi tiruan, sampel terlebih dahulu dilakukan pemotretan dengan menggunakan Panoramic $x$-ray unit oleh ahli radiologi kedokteran gigi. Kemudian dilakukan pengamatan densitas dengan alat densitometer pada 4 titik yang telah ditentukan yaitu 2 di anterior (kaki) dan 2 posterior (ka-ki). Pengukuran bagian anterior dilakukan jarak $1,5 \mathrm{~cm}$ dari garis median kearah daerah gigi kaninus. Pengukuran bagian posterior dilakukan pada jarak $1,5 \mathrm{~cm}$ dari tepi posterior foramen mentale. Cara ini juga dilakukan kembali setelah 2, 4, dan 6 bulan.

\section{Pengukuran ketinggian tulang alveolar mandi- bula}

Penggunaan teknik pengukuran ketinggian tulang alveolar mandibula pada penelitian ini ditentukan pada daerah foramen mentale. Sebelum dilakukan pengukuran, terlebih dahulu ditentukan tempat relatif foramen mentale. Teknik pengukuran ketinggian tulang menggunakan metode ${ }^{8}$, yaitu:

a. Mengukur tinggi mandibula pada daerah foramen mentale disebut dengan garis a.

b. Menentukan persentase kehilangan tulang alveolar, dengan menggunakan metode Wical dan 
Swoope $^{8}$ yaitu, mengukur jarak tepi bawah mandibula sampai tepi bawah foramen mentale (c), selanjutnya memperkirakan hingga 3 kali tinggi tulang mandibula pada tepi bawah foramen mentale $(3 \times \mathrm{c})$. Perkiraan 3 kali tinggi tulang ini merupakan perkiraan tinggi tulang alveolar mandibula yang original. Persentase kehilangan tulang alveolar dapat dihitung dengan menggunakan rumus: $\{[3 \times \mathrm{c}-\mathrm{a}] / 3 \times \mathrm{c}\} \times 100 \%$.

c. Mengukur tinggi tulang alveolar mandibula dengan cara menghitung nilai riil dari persentase kehilangan tulang alveolar mandibula yaitu mengalikan persentase kehilangan tulang dengan tiga kali garis c. Selanjutnya menghitung hasil pengurangan 3 kali panjang garis $\mathrm{c}$ dengan nilai kehilangan tulang alveolar.

Hasil pengukuran selanjutnya diuji dengan menggunakan Anova one-way dengan tingkat kepercayaan $95 \%(\alpha=0,05)$.

\section{Hasil Penelitian}

1. Data hasil pengukuran densitas tulang alveolar mandibula sebelum dan setelah pembuatan gigi tiruan dengan tissue conditioner

Rerata hasil pengukuran densitas tulang alveolar mandibula sebelum dan setelah pembuatan gigi tiruan dengan tissue conditioner telah tercantum pada Tabel 1 .

Tabel 1. Rerata pengukuran densitas tulang alveolar sebelum dan setelah pembuatan gigitiruan dengan tissue conditioner

\begin{tabular}{|c|c|c|c|c|}
\hline \multirow{3}{*}{ Sampel } & \multicolumn{4}{|c|}{$\begin{array}{c}\text { Rerata Nilai Densitas Tulang Alveolar } \\
\text { Mandibula }\left(\mathrm{gr} / \mathrm{cm}^{2}\right)\end{array}$} \\
\hline & \multicolumn{2}{|c|}{ Anterior } & \multicolumn{2}{|c|}{ Posterior } \\
\hline & Kanan & Kiri & Kanan & Kiri \\
\hline I & $1,797 \pm$ & $1,754 \pm$ & $1,764 \pm$ & $1,742 \pm$ \\
\hline & 0.14 & 0,12 & 0,12 & 0,12 \\
\hline II & $\begin{array}{l}1,788 \pm \\
0,14\end{array}$ & $\begin{array}{l}1,741 \pm \\
0,11\end{array}$ & $\begin{array}{l}1,764 \pm \\
0,11\end{array}$ & $\begin{array}{l}1,732 \pm \\
0,12\end{array}$ \\
\hline III & $\begin{array}{c}1,779 \pm \\
0,13\end{array}$ & $\begin{array}{l}1,730 \pm \\
0,11\end{array}$ & $\begin{array}{c}1,734 \pm \\
0,10\end{array}$ & $\begin{array}{l}1,714 \pm \\
0,11\end{array}$ \\
\hline IV & $\begin{array}{l}1,762 \pm \\
0,13\end{array}$ & $\begin{array}{l}1,714 \pm \\
0,12\end{array}$ & $\begin{array}{l}1,732 \pm \\
0,10\end{array}$ & $\begin{array}{l}1,701 \pm \\
0,12\end{array}$ \\
\hline
\end{tabular}

Keterangan:

Sampel I: Pengukuran dilakukan sebelum pemasangan gigi tiruan

Sampel II: Pengukuran dilakukan setelah 2 bulan pemasangan gigi tiruan
Sampel III: Pengukuran dilakukan setelah 4 bulan pemasangan gigi tiruan

Sampel IV: Pengukuran dilakukan setelah 6 bulan pemasangan gigi tiruan

Berdasarkan Tabel 1 diatas, dapat diketahui bahwa adanya sedikit kecenderungan penurunan densitas tulang alveolar pada pemakai gigi tiruan yang terlibat pada penelitian ini. Nilai densitas $\left(\mathrm{gr} / \mathrm{cm}^{2}\right)$ pada berbagai sampel sebelum dan setelah penggunaan gigi tiruan dengan penggunaan tissue conditioner pada wanita pasca menopause bervariasi antara $1,59-2,02$.

2. Data hasil pengukuran ketinggian tulang alveclar mandibula sebelum dan setelah pembuatan gigi tiruan dengan tissue conditioner

Rerata hasil pengukuran ketinggian tulang alveclar mandibula sebelum dan setelah pembuatan gigi tiruan dengan tissue conditioner telah tercantum pada Tabel 2.

Tabel 2. Rerata pengukuran ketinggian tulang alveolar mandibula sebelum dan setelah pembuatan gigi tiruan dengan tissue conditioner

\begin{tabular}{|c|c|c|}
\hline \multirow[b]{2}{*}{ Sampel } & \multicolumn{2}{|c|}{$\begin{array}{l}\text { Rerata pengukuran ketinggian tulang } \\
\text { alveolar mandibula (mm) }\end{array}$} \\
\hline & Mandibula Kanan & Mandibula Kiri \\
\hline I & $20,455 \pm 1,91$ & $20,208 \pm 1,62$ \\
\hline II & $20,168 \pm 2,22$ & $20,058 \pm 1,65$ \\
\hline III & $19,424 \pm 1,49$ & $18,855 \pm 1,55$ \\
\hline IV & $19,137 \pm 1,63$ & $18,571 \pm 1,17$ \\
\hline
\end{tabular}

Hasil uji Analysis of varian didapatkan $\mathrm{p}>$ 0,05 untuk semua kelompok uji. Hal ini berarti menunjukkan tidak ada perbedaan yang bermakna untuk densitas tulang alveolar mandibula pada bagian anterior dan posterior sebelah kanan dan kiri pada saat sebelum dan setelah 2, 4, dan 6 bulan penggunaan gigi tiruan dengan tissue conditioner pada wanita pasca menopause.

\section{Pembahasan}

Bagi seorang wanita lanjut usia yang telah memasuki masa post menopause dan menggunakan gigi tiruan, seringkali mendapatkan permasalahan adanya rasa sakit pada daerah jaringan pendukung gigitiruan. Hal ini dapat disebabkan menipisnya epithel, sehingga perlu dipertimbangkan penggunaan soft liner denture pada tissue bearing area 
tiruannya. Berbagai keluhan lain yang sering muncul adalah adanya keluhan rasa sakit pada rahang bawah ataupun gigi tiruan yang tidak cekat atau mudah lepas dari tempat kedudukannya. Keluhan ini apabila tidak dilakukan evaluasi secara adekuat dapat menimbulkan masalah yang lebih kompleks, antara lain motivasi penderita untuk memakai gigi tiruan cenderung turun. Hilangnya motivasi akan menimbulkan keengganan memakai gigitiruan tersebut, sehingga gerakan pengunyahan dapat mengalami perubahan dan akhirnya dapat menimbulkan perubahan posisi kondili pada fossa glenoid.

Penelitian ini dilakukan dengan menghitung perubahan densitas dan ketinggian tulang alveolar mandibula setelah penggunaan gigitiruan dengan tissue conditioner selama 2, 4, dan 6 bulan. Pada penelitian ini dilakukan pada rahang bawah yang didasarkan dari berbagai hasil penelitian yang telah dilakukan, menunjukkan bahwa resorbsi yang progresif merupakan salah satu penyebab utama hilangnya stabilitas dan retensi dari gigi tiruan lengkap rahang bawah. ${ }^{8} \mathrm{Hal}$ ini disebabkan rahang bawah merupakan bagian yang mengalami tekanan lebih besar dan juga selalu melakukan aktivitas (mobile), sehingga tekanan yang didapat lebih besar dibandingkan dengan rahang atas. Di samping itu, rahang bawah juga mendapat nutrisi yang sedikit dari pembuluh darah dibandingkan rahang atas yang kaya akan pembuluh darah, sehingga pertumbuhannya sedikit dan proses resorbsi lebih banyak.

Faktor lain adalah adanya keluhan rasa sakit pada daerah premolar rahang bawah yang sering didapatkan pada penderita yang berusia lanjut. Secara anatomis hal ini seringkali dihubungkan dengan lokasi foramen mentale. Tekanan dari gigi tiruan telah dilaporkan menyebabkan paresthesia di daerah nervus mentale. Lokasi foramen mentale dapat mudah diidentifikasi dengan panoramic radiograph. Metode ini diharapkan dapat mempermudah sekaligus meningkatkan validitas penghitungan ketinggian tulang mandibula. ${ }^{8}$

Penggunaan bahan tissue conditioner sebagai salah satu bahan pelapis gigitiruan dapat diartikan agar beban pengunyahan dapat dibagi lebih merata, sehingga memungkinkan jaringan mukosa di bawahnya merasa berada pada posisi normal. Di samping itu, keberadaan bahan ini juga dapat mencegah rasa nyeri yang disebabkan karena tekanan atau gerakan gigi tiruan sewaktu pengunyahan. ${ }^{6}$ Keadaan ini, seringkali didapatkan pada wanita usia lanjut yang mengalami pasca menopause. Pada masa pasca menopause ini, produksi hormon estrogen menurun, dimana estrogen dapat mengurangi sintesis interleukin-6 yang berperan menstimulasi resorbsi tulang. ${ }^{1}$ Bila resorbsi yang progresif ini melibatkan pada rahang bawah, terutama pada daerah foramen mentale akan menimbulkan keluhan nyeri.

Penelitian ini menggunakan tissue conditioner sebagai bahan pelapis basis gigi tiruan dan dilakukan pengukuran densitas tulang dengan menggunakan densitometer. Hasil penelitian ini menunjukkan nilai densitas tulang yang rata-rata cenderung di bawah nilai normal dengan rentang usia. Keadaan ini dapat disebabkan pengurangan hormon estrogen, sehingga dapat menyebabkan gangguan sintesis $1,25(\mathrm{OH})_{2}$ $\mathrm{D}_{3}$ serta mempengaruhi absorbsi kalsium dari diet yang juga dapat mengakibatkan tulang menjadi tipis dan rapuh. Pengurangan massa tulang dan perubahan mikrostruktur tulang ini disebut osteoporosis.' Pernyataan ini sesuai dengan pernyataan Kribbs $(1990)^{5}$ dan Marei (1997) ${ }^{9}$ yang menyatakan bahwa berkurangnya densitas tulang mandibula mempunyai kecenderungan dengan terjadinya osteoporosis dan proses ini akan berjalan secara lambat.

Berdasarkan hasil penelitian ini, tidak menunjukkan perbedaan yang signifikan $(p>0,05)$ pada densitas tulang alveolar mandibula. Hal ini dimungkinkan karena alkyl maleate atau alkyl itaconate yang terkandung pada bahan tissue conditioner menghasilkan polimer dengan berat molekul lebih rendah sehingga masih mampu berperan sebagai plastisizer dalam rentang waktu tersebut. Hal ini yang membuat bahan tissue conditioner menjadi lunak, sehingga dapat meningkatkan kekenyalan dan perlekatan yang lebih kuat terhadap basis gigi tiruan. ${ }^{6}$ Keadaan ini jelas menguntungkan terhadap jaringan pendukung gigi tiruan karena dapat mengurangi beban kunyah yang mengenainya. Dengan konsep mucosa borne pada pembuatan gigi tiruan lengkap, maka beban kunyah secara menyeluruh akan diterima oleh tulang alveolar, sehingga diperlukan upaya untuk menyebarkan beban kunyah seluas mungkin. Hal ini akan menurunkan tekanan per unit area pada daerah tissue bearing surface, sehingga mampu memelihara jaringan pendukung gigi tiruan.

Hasil penelitian ini juga menunjukkan perbedaan yang tidak signifikan pada pengukuran ketinggian tulang alveolar mandibula. Hal ini sesuai dengan penelitian Timo $(1997){ }^{8}$ yang menyatakan resorbsi ridge secara progresif akan menurunkan jaringan penyangga gigitiruan, tetapi perubahan ini berjalan lambat. Adanya penurunan tulang alveolar pada salah seorang subyek penelitian ini dapat dihubungkan dengan aktivitas pencabutan yang dilakukan sebelum pembuatan gigi tiruan. 
Berdasarkan hasil penelitian ini, diketahui bahwa bahan tissue conditioner mampu berperan sebagai peredam kekuatan kunyah yang mengenai tulang alveolar, sehingga dapat memelihara jaringan pendukung gigitiruan. Tetapi, bagaimanapun juga, penggunaan bahan ini tetap memerlukan kontrol periodik agar tidak menjadi keras yang disebabkan terlepasnya bahan plastisizer sewaktu berkontak dengan saliva, sehingga dapat mencegah terjadinya perubahan dimensi atau menjadi kerasnya bahan ini.

\section{Kesimpulan}

a. Tidak ada perbedaan yang bermakna untuk densitas dan ketinggian tulang alveolar mandibula sebelum dan setelah penggunaan gigi tiruan dengan tissue conditioner selama 2, 4, dan 6 bulan pada wanita pasca menopause.

b. Pemberian tissue conditioner pada gigitiruan yang digunakan oleh wanita usia lanjut pasca menopause efektif mempertahankan kualitas tulang alveolar mandibula selama 2, 4, dan 6 bulan.

\section{Saran}

Perlunya dilakukan penelitian lebih lanjut dengan memperpanjang waktu kontrol setelah penggunaan bahan tissue conditioner serta interaksi dengan mikroorganisme rongga mulut.

\section{Ucapan Terima Kasih}

Penulis mengucapkan terima kasih kepada Universitas Jember yang telah memberikan dana untuk biaya penelitian melalui Proyek Peningkatan
Penelitian Pendidikan Tinggi (P4T) Dirjen Dikti Depdiknas Tahun Anggaran 2004 tentang Pelaksanaan Penelitian Dosen Muda Nomor: 113/ P4T/ DPPM/DM,SKW,SOSAG/III/2004 Tanggal 25 Maret 2004

\section{Daftar Pustaka}

1. Kusdhani L, Mulyono G, Baskara ES, Oemardi M, dan Budi WR. Kualitas Tulang Mandibula pada Wanita Pasca Menoupause. JDUI 2000; 7 (ed.khusus KPPIKG XII): 673-8.

2. Winasa IG. Perubahan Jaringan Rongga Mulut Pada Usia Lanjut. MKGI 1995; 1:15-8.

3. Kahardjo TB, Hazmia A., Farisza GR, dan Bambang Sił. Peran Tim Bidang Kedokteran Gigi Dalam Pelayanan Geriatri Terpadu. JDUI 2000; 7 (ed.khusus KPPIKG XII) :684-8.

4. Rurri A. Proses Menua Pada Jaringan Lunak Rongga Mulut. Kumpulan Makalah Ilmiah FKG UI. 1994; 661-4.

5. Kribs PJ. Comparison of Mandibula Bone in Normal and Osteoporotic Women. J Prosthet Dent. 1990; 63:218-22.

6. Combe EC, Notes on Dental Material. 6th edition, Edinburg: Churchil Livingstone. 1992; 79-120.

7. Basker RM, Davenport JC dan Tomlin HR. Prosthetic Treatment of Edentulous Patient. 1st ed., London : The Macmillan Press Ltd. 1976; 163-5.

8. Timo ON, Ronald LE, dan Ernest WM. Radigraph Findings Ridge Resorption and Subjective Complaints of Complete Denture Patient. Int J Pros. 1997; 10:183-8.

9. Marei MK, Zahran M, dan Naoman F. A Comparative Study of The Effect of Three Different Denture Base Material on The Rate of Changes of mandibular Alveolar Bone Height anf Density in Osteoporotic Female. Saudi Dental J 1997; 1: 21-9. 